\title{
New application of open source data and Rock Engineering System for debris flow susceptibility analysis
}

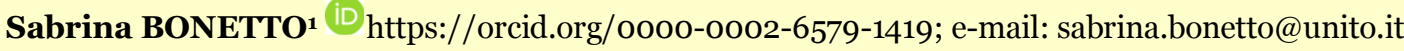 \\ Pietro MOSCA2 ${ }^{\text {iD } h t t p s: / / o r c i d . o r g / o o o o-0 o o 2-7517-5353 ; ~ e-m a i l: ~ p i e t r o . m o s c a @ c n r . i t ~}$ \\ Federico VAGNON1* (D https://orcid.org/oooo-0003-0539-0557; e-mail: federico.vagnon@unito.it

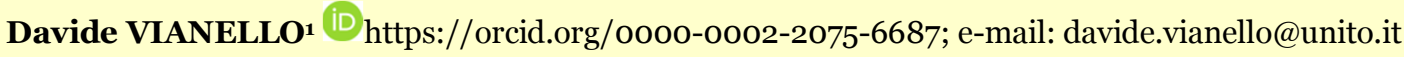 \\ *Corresponding author \\ 1 Department of Earth Science, University of Torino, Torino 10125, Italy \\ 2 Institute of Geosciences and Earth Resources, National Research Council (CNR), Torino 10125, Italy
}

Citation: Bonetto S, Mosca P, Vagnon F, et al. (2021) New application of open source data and Rock Engineering System for debris flow susceptibility analysis. Journal of Mountain Science 18(12). https://doi.org/10.1007/s11629-021-6814-3

(C) The Author(s) 2021.

\begin{abstract}
This research describes a quantitative, rapid, and low-cost methodology for debris flow susceptibility evaluation at the basin scale using open-access data and geodatabases. The proposed approach can aid decision makers in land management and territorial planning, by first screening for areas with a higher debris flow susceptibility. Five environmental predisposing factors, namely, bedrock lithology, fracture network, quaternary deposits, slope inclination, and hydrographic network, were selected as independent parameters and their mutual interactions were described and quantified using the Rock Engineering System (RES) methodology. For each parameter, specific indexes were proposed, aiming to provide a final synthetic and representative index of debris flow susceptibility at the basin scale. The methodology was tested in four basins located in the Upper Susa Valley (NW Italian Alps) where debris flow events are the predominant natural hazard. The proposed matrix can represent a useful standardized tool, universally applicable, since it is independent of type and characteristic of the basin.
\end{abstract}

Keywords: Debris flow; Interaction matrix; Rock Engineering System (RES); Susceptibility analysis; Open source data; Debris flow predisposing factors.

Received: 26-Mar-2021

Revised: 15 -Jun-2021

Accepted: 09-09-2021

\section{Introduction}

Landslides are one of the most dangerous natural events that affect the physical, human, and industrial environments on Earth (Jakob et al. 2005). Among all landslide types, debris flows are the most destructive due to their unpredictability, their high runout velocity, and their high travel distance (Calligaris and Zini 2012). Loose unsorted material of low plasticity such as that produced by mass wasting processes (colluvium), weathering, glacier transport, explosive volcanism or human activities (e.g. mine spoil) may be mobilized as a consequence of a great amount of water (e.g. heavy rainfall, snow and ice melt, dam break events).

The system of hazardous conditions generated by the interaction of these geomorphological and geological features, water saturation, and propagation velocity is very complex and difficult to forecast (Skempton et al. 1969; Varnes 1978; Hutchinson 1988; Coussot and Meunier 1996; Cruden and Varnes 1996; Lorenzini and Massa 2004). Consequently, the identification of the mutual interactions between geomorphological and geological features and the socio-economic fabric becomes fundamental for 
hazard mapping and defining the best risk management strategy (Vagnon et al. 2015; Vagnon et al. 2019; Vagnon 2020).

For developing plans and/or implementing appropriate risk mitigation measures, landslide susceptibility, hazard and risk maps are essential for depicting the areas potentially affected by debris flows (Corominas et al. 2014; Vagnon et al. 2020a, 2020b). A large number of methodologies have already been established to assist in risk management decisions (Guzzetti et al. 1999; Carrara et al. 1999; Glade et al. 2005) and several suggestions and guidelines have been proposed (Cascini et al. 2005; Corominas et al. 2014 and references herein).

In general, risk must be quantified with reference to a given time period, for an expected frequency or probability of occurrence of an event, with an intensity higher than a minimum established value. The process of quantitative risk analysis (QRA) is fundamental as it provides an objective and reproducible risk evaluation, and the results are spatially independent (they can be compared from one location to another). In a multi-hazard landslide risk assessment, various steps of analysis are proposed. The first step deals with the input data required to generate susceptibility maps (Van Westen et al. 2006), according to Cascini et al. (2005) who consider the mapping of susceptible areas within a basin as a useful application of passive interventions aimed at risk mitigation.

Landslide susceptibility refers to the possibility that a landslide may occur in a given area, under specific conditions (Brabb 1987), with a resulting susceptibility map identifying zones prone to landslides (Kavoura et al. 2020). Susceptibility considers the spatial distribution of landslide predisposing environmental factors that are expected to influence the occurrence of landslides. The predisposing factors, such as geology of bedrocks and deposits, geomorphology, hydrological conditions, and topography (Radbruch 1970; Brabb 1987), are specific to landslide types and failure mechanisms and consequently are given different weights in each instability phenomenon (Cruden and Varnes 1996).

The relationship between predisposing factors and landslide susceptibility have been obtained using both qualitative, such as inventory-based and knowledge-driven methods, and quantitative methods, such as data-driven and physically based models. A detailed overview of these methods is available in
Corominas et al. (2014). All these methods demonstrated that as more technical information becomes available, as rock engineering projects become more complicated, as environmental issues become more significant, and as more emphasis is placed on quality assurance, there is need to provide procedural guidance to analyse all rock-engineering problems (Hudson 1992). Thus, the identification and quantification of parameters that affect the events, and their interaction, is the basic requirement for a proper technical approach to the problem (Vagnon et al. 2015, 2017).

With the development of remote sensing techniques and geographic information systems (GIS), most of the predisposing factors are available as spatial data at the basin scale and are accessible freeof-charge in national and regional geodatabases. Consequently, these data are used as a first-step in our basin-scale susceptibility analysis.

This research describes the design and implementation of a quantitative, rapid and low-cost methodology for debris flow susceptibility analysis in order to help decision makers in a first step screening for areas most susceptible to this phenomenon. Five environmental predisposing factors were selected as independent parameters and their mutual interactions were quantified using the Rock Engineering System (RES) methodology (Hudson 1992): i) bedrock lithology, ii) the fracture network, iii) unconsolidated Quaternary deposits, iv) slope inclination and v) hydrographic network.

The selection of these parameters was based on a deep knowledge of debris flow phenomena achieved after years of study in this field (Zimmerman and Haeberli 1992; Iverson 1997; Jakob et al. 2005; Takahashi 2007 and references herein) and on valuable works of other researchers where RES was successfully applied to landslides (Rozos et al. 2008; Tavoularis et al. 2018). Moreover, their choice was made following five criteria (Ayalew et al. 2005): 1) representative of the whole basin, 2) spatial variation, 3) easily measurable, 4) no two or more factors are duplicative, 5) known or generally accepted to be associated with debris flows through the established past years of research.

For each parameter, specific indexes were proposed for developing a standardized, universally applicable tool. The RES is able to describe and score the relationship and interactions among all the selected factors, furnishing a synthetic and 
representative index of debris flow susceptibility. RES combines objectivity and efficiency (Rozos et al. 2008) and allows for the analysis of rock engineering problems from a systematic perspective, using a matrix approach. It has been used in tunnelling applications and slope and mining instability analyses (Mazzoccola et al. 1996; Kim et al. 2008; Rozos et al. 2008; Tavoularis et al. 2018 and references herein) but, as far as the authors know, it has never been used as a basic tool for representing the parameters and interaction mechanisms associated with debris flow phenomena.

The efficiency of this innovative methodology was tested in four hydrological basins located in the Upper Susa Valley (NW Italian Alps) where numerous debris flow events were identified and analysed from "SIFRAP landslides Inventory (ARPA Piemonte
2011)", basin scale studies (e.g. Tiranti et al. 2015; Tiranti et al. 2016) and local land-use plan (Oulx Municipality 2012).

\section{Study Area}

\subsection{Regional geological settings}

The hydrological basins considered in this study are located in Upper Susa Valley (Fig. 1a) which is one of the major valleys of the Western Alps (NW Italy) and is drained by the Dora Riparia River, a left-hand tributary of the Po River. The valley landscape results from prolonged erosion by glaciers at the end of the Late Pleistocene. Glacial deposits and erosional landforms are widespread. The glacial retreats

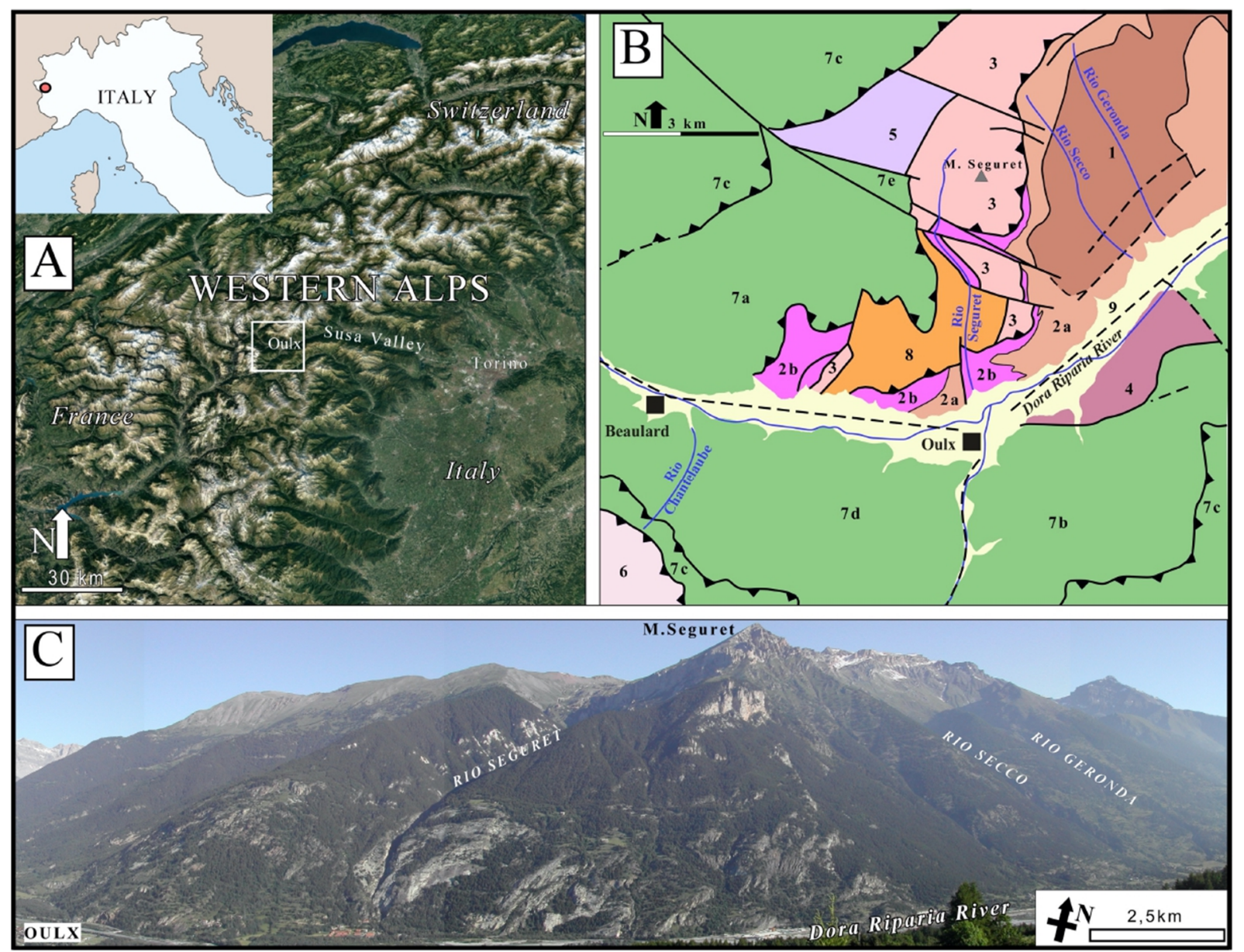

Fig. 1 a) Google image showing location of Susa Valley in the Italian Western Alps (red dot in the insert) (C) Google Maps). b) Tectonic sketch map of the part of the Upper Susa Valley (after Servizio Geologico d'Italia 2002). Continental margin unit: 1-Clarea Unit; 2a- Pre-Triassic and 2b-Mesozoic rocks of the Ambin Unit; 3-Vallonetto Unit; 4- Gad Unit; 5-Valfredda Unit; 6-Chaberton-Grand Hoche-Grand Argentier unit. Oceanic Units: 7a-Aigle Unit; 7bCerogne-Ciantiplagna Unit, 7c-Lago Nero Unit, 7d-Puy Venaus Unit; 7e-Vin Vert Unit. 8-Gypsum and tectonic carbonate breccias. 9- Alluvial deposits. c) Panoramic view of the left side of the Upper Susa Valley. SR:WGS84/UTM zone $32 \mathrm{~N}$. 
favoured widespread occurrence of deep-seated gravitational slope deformations on the valley flanks (Polino et al. 2002).

The Western Alps consist of different units derived from European and Adria continental plates and from their interposed Piedmont-Ligurian oceanic basin, juxtaposed and metamorphosed during subduction and continental collision-related processes (e.g. Dal Piaz 2010).

Along the Upper Susa Valley transect, continental margin units (Ambin Massif Auct, Pre-Piedmont and Briançonnais units) and ocean-derived PiedmontLigurian units are juxtaposed by west-dipping tectonic contacts (Malusà et al. 2002; Polino et al. 2002; Piana et al. 2017) (Fig. 1b).

The Ambin massif Auct. consists of two prealpine units, i.e. the Clarea and Ambin units, resting in lower and upper structural levels respectively (e.g. Malusà et al. 2002; Mosca et al. 2008).

The prevailing rock type of the Clarea unit is quartz-bearing micaschist, containing bodies of metabasites and masses of orthogneiss. The Ambin unit consists of several types of micaschist and gneiss embedding metabasites and locally intruded by aplitic gneiss. These rocks are unconformably overlain by a Mesozoic cover starting with Upper Permian quartzose microconglomerate and Lower Triassic massive quartzite. Then, upsection Middle Triassic to Cretaceous metacarbonate rocks occur, dominated by dolomitic marble and calcareous schist (calcschist) with local intercalation of carbonate breccias. The Briançonnais unit mainly consists of marble and dolomitic marble of Triassic age, upsection followed by Jurassic to Cretaceous calcschist. The ChabertonGrand Hoche-Grand Argentier unit (belonging to the Pre-Piedmont zone) consists of a thick Norian dolomitic succession upwards passing to RhaetianHettangian calcschist, and Jurassic calcareous schist and phyllite with discontinuous beds of breccias.

Several ophiolite-bearing Ligurian-Piedmont units are mapped in this sector of the Western Alps (Polino et al. 2002; Piana et al. 2017). These units consist of prevailing Upper Jurassic (?)-Cretaceous calcschist with intercalations of micaschist and phylladic schist and embedding different amounts of ophiolites. In addition, large masses of gypsum and discontinuous bodies of carbonate breccias (Carniole Auct.) occur along main tectonic contacts.

The bedrocks are variably covered by different types of Quaternary glacial deposits, landslides, and recent detrital deposits (Polino et al. 2002; Servizio Geologico d'Italia 2002; Piana et al. 2017).

Four basins were chosen based on morphometrical and geological features, hydrological settings, and number of recorded events.

\subsection{Analysed basins}

The Rio Secco, Rio Geronda and Rio Seguret basins are located on the left side of the Susa Valley (Fig. 1c), and the Rio Champeiron basin on the right one. All the basins have an extent ranging from $\sim 3$ to $\sim 10 \mathrm{~km}^{2}$, and their uppermost parts are characterized by steep cliffs.

From 1728 to 2015, these four basins were affected by several debris flow events recorded in the "SIFRAP landslides Inventory" (ARPA Piemonte 2011) and Oulx's land-use plan (Oulx Municipality 2012). These events caused socio-economic damage to the urbanized areas near the channel streams. No information about the source areas was available, only the event date and brief qualitative descriptions of the events.

The major lithologies of the Rio Geronda basin are micaschists and gneisses of the Clarea and Ambin units (Fig. 2a), deeply incised in the mid to lower basin. Widespread eluvio-colluvial deposits cover the left sectors of the basin and local patches of glacial deposits are located in the upper basin (Fig. 2b).

The Rio Secco basin includes lithologies similar to those of the Rio Geronda basin (Fig. 2a), but its head consists of quartzites (Mesozoic cover of the Ambin Unit). On the right side of the basin, the sources of tributary streams can reach marble and dolomitic marble (upper part of the Ambin Unit cover and the Vallonetto unit). The Rio Secco basin is almost entirely incised in bedrock with micaschist, gneiss and quartzite talus (Fig. 2b).

The uppermost part of the Rio Seguret basin is located in Vallonetto Unit marble (Fig. 2a). The remaining part of the basin consists of quartzites (deeply incised in the lower part of the basin) and carbonate rocks of the Ambin Unit. Mid-basin, Gypsum is exposed on the right and left sides, and crossed by a few tributary streams. Deposits are composed of carbonate rock talus and landslide deposits (Fig. 2b).

The Rio Campheiron basin is characterized by dolomitic marbles and carbonate schists (ChabertonGrand Hoche unit) at its uppermost part, and 

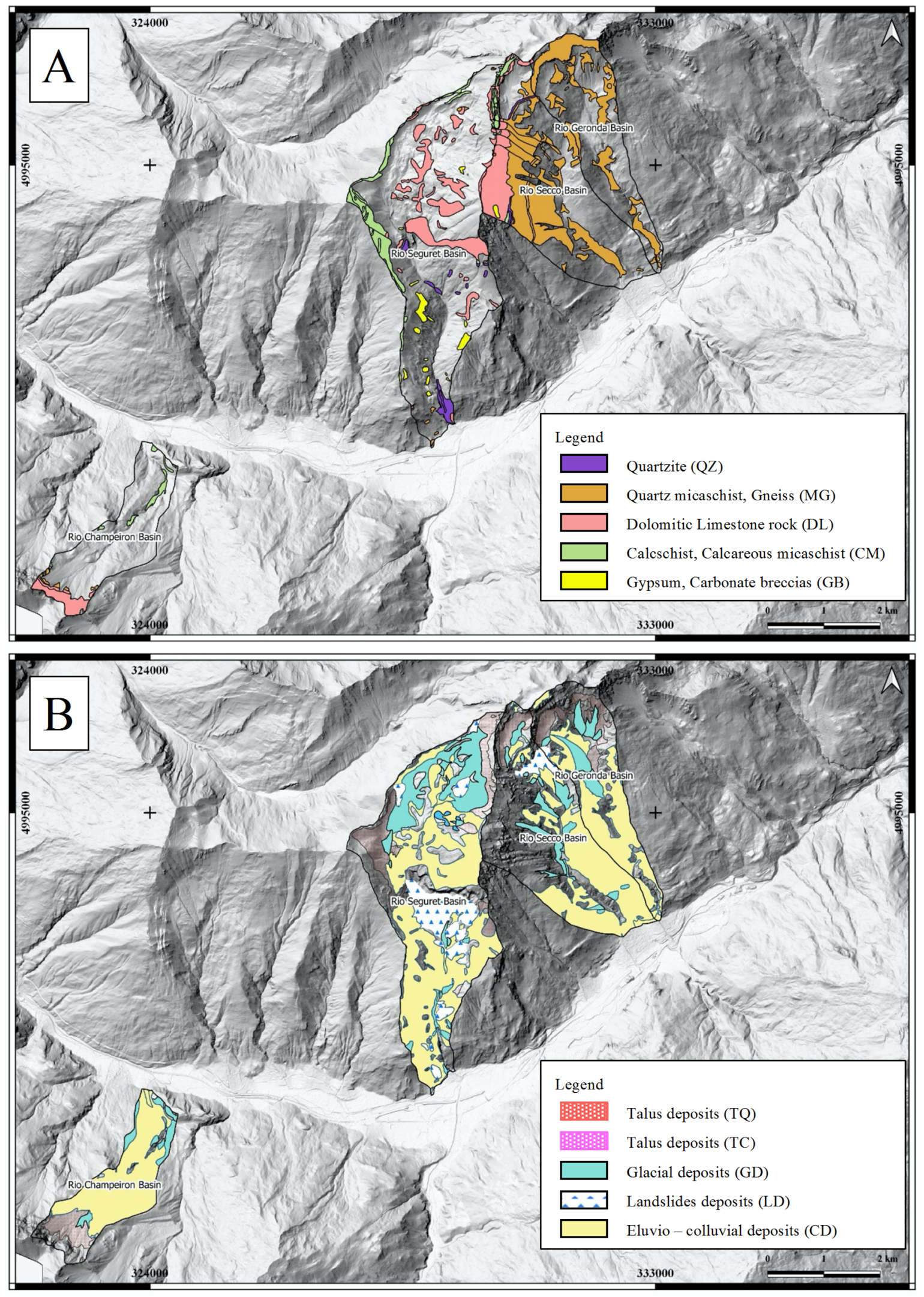

Fig. 2 Distribution of a) the bedrock lithology and b) the Quaternary deposits in the studied basins (after Servizio Geologico d'Italia 2002). SR: WGS84/UTM zone 32N. 
carbonate schists (Piedmont-Ligurian unit) are mapped in the middle-lower part of the basin (Fig. 2a). Eluvio-colluvial deposits cover large portions of the basin, while glacial deposits have been locally identified in the lower part of the basin. At the catchment of the basin, talus cones of prevailing carbonate rocks are present (Fig. 2b).

\section{Methodology}

\subsection{Rock Engineering System (RES)}

The interaction between the main geological and geomorphological predisposing parameters can be analysed using the Rock Engineering System (RES) proposed by Hudson (1992). This approach is an objective-based methodology and allows using all the existing information to hierarchically classify and score the involved parameters in a rational way. For this purpose, an interaction matrix is created: it summarizes the key geotechnical, geological, and geomorphological parameters that influence debris flows and quantifies their mutual interactions for assessing the debris flow susceptibility of an alpine basin.

Fig. 3 shows the main principles of the interaction matrix. The relevant parameters are placed along the leading diagonal (diagonal terms, $P_{i}$ ) and the influence of the parameter on the others is located at the correspondent intersection (offdiagonal terms, $\left.I_{i j}\right)$ between the diagonals term. Along the diagonal, the parameters are hierarchically placed: first those linked to the rock mass and finally those related to in situ conditions.

If the diagonal-off terms are scored, the interaction matrix becomes a computation matrix and it's possible to numerically define the parameter dominance and to graphically represent the cause/ effect relationship.

There are qualitative and quantitative code methods: in this research, the authors used the Expert Semi-Quantitative (ESQ) method (Harrison and Hudson 2006; Vagnon et al. 2015) which introduces a rating from $\mathrm{o}$ to 4 , corresponding to no interaction, weak interaction, medium interaction, strong interaction, and critical interaction.

Analysing the physical meaning of the matrix (Fig. 3), the row passing through leading parameter $P_{i}$ can be interpreted as the influence of $P_{i}$ on all other parameters in the system. On the other hand, the column through $P_{i}$ represents the influence of the system on $P_{i}$. Furthermore, the sum of each row is the cause $(C)$ and the sum of each column is the effect $(E)$. Thus, $\mathrm{C}$ represents the way in which $P_{i}$ affects the system and $\mathrm{E}$ represents the effect that system has on

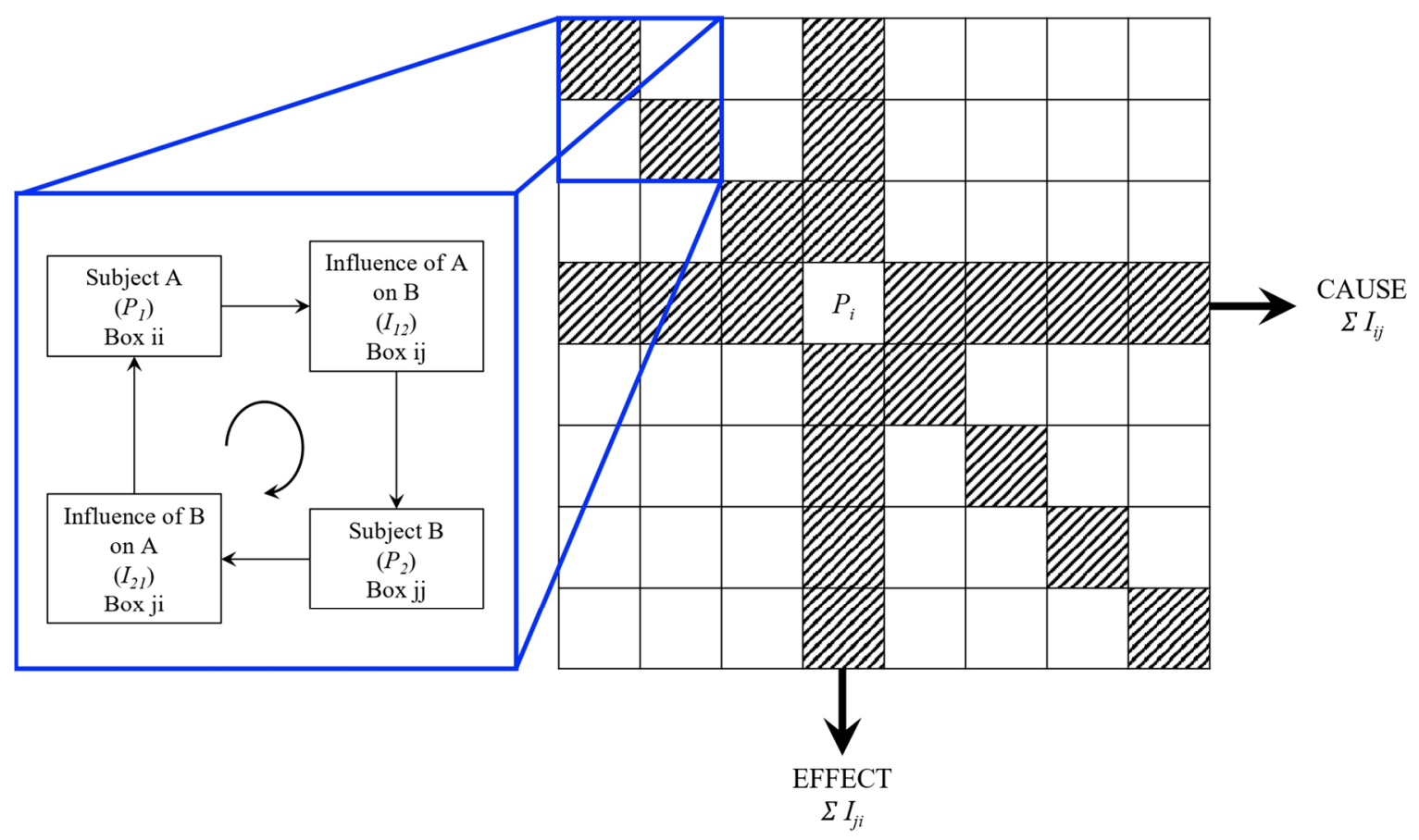

Fig. 3 Operating principles and physical meaning of the interaction matrix. 
$P_{i}$. Once $\mathrm{C}$ and $\mathrm{E}$ are defined, the next step is to compute the "Debris flow Propensity Index" (DfPI) for the considered basin ( $j$ ), by using the following equation:

$$
\operatorname{DfPI}_{j}=\sum\left(a_{i} \cdot P_{i k}\right)
$$

where $i$ refers to predisposing parameters and $k$ refers to the examined basin and $a_{i}$ is the weighting coefficient of each parameter given by:

$$
a_{i}=\frac{1}{\max \left(I_{i j} j_{t h}\right)} \cdot\left[\frac{C+E}{\sum I_{i j}+\sum I_{j i}}\right] \cdot 100
$$

With $I_{i j t h}$ is the maximum value that the offdiagonal term can assume (in this case is equal to 4 ).

$P_{i k}$ is a specific index that describes the influence of each predisposing factor to generate debris flow events.

A detailed description of each $P_{i k}$ is given in the following sub-sections by introducing specifically developed indexes for each predisposing factor, taking inspiration by other studies on RES landslide applications (Rozos et al. 2008; Tavoularis et al. 2018 and references herein).

According to RES principles, an interaction matrix for the analysis of debris flow susceptibility was developed to weight the contribution of each predisposing parameter in relation to their mutual interaction.

Fig. 4 summarizes the logical flow and the main steps for evaluating DfPI.

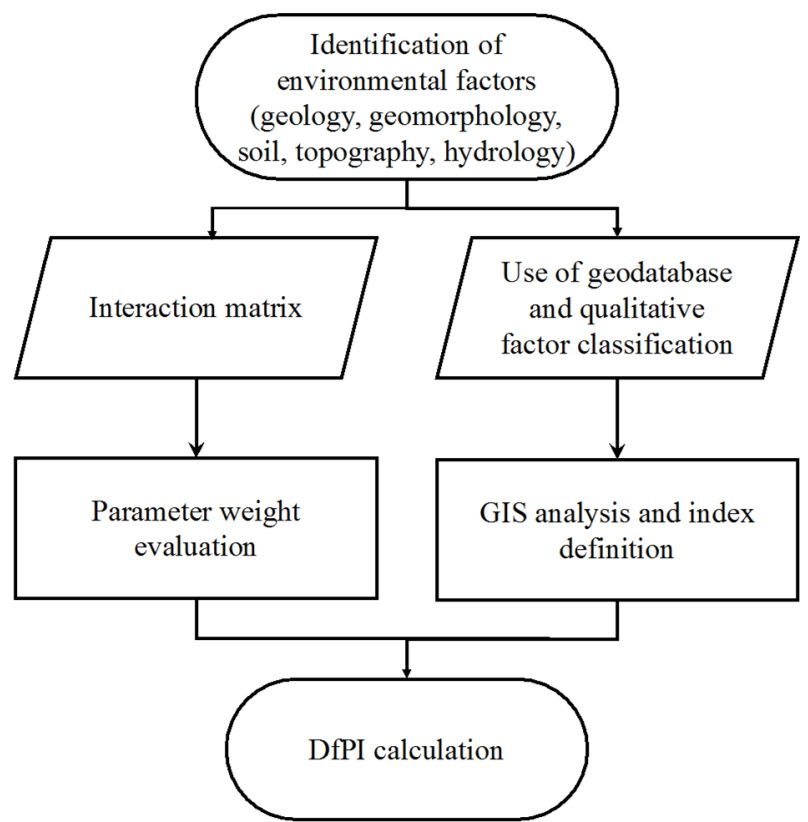

Fig. 4 Main steps of the proposed methodology.

\subsection{Pik index definition}

To define a user-friendly, fast, and low-cost methodology for debris flow susceptibility zonation at a basin scale, QGIS software was used for processing open-source geodatabases (e.g. http://www. geoportale.piemonte.it/geocatalogorp/?sezione=catal ogo/, 2020).

The geological data (bedrock lithology and Quaternary deposits) were obtained from the Italian Geological Cartography CARG-Project at 1:50 ooo scale. Geomorphological features, such as slope and hydrographic network, were developed with a $5 \mathrm{~m}$ resolution digital elevation model (DEM) of the study area. A lineaments network was extracted through remote sensing surveys and aerial image analyses.

In the following sections, a detailed description of the predisposing factor indexes is given.

\subsubsection{Bedrock lithology}

Different lithologies have different susceptibility to produce landslide and debris flow occurrence (Xu et al. 2013). Mineralogy, texture, and fabric influence the shear strength, the permeability, the susceptibility to chemical and physical weathering of rocks, which in turn affect the slope stability (Varnes 1978; Rozos et al. 2008; Tavoularis et al. 2018) and debris flow generation.

A qualitative strength classification $\left(S_{L}\right)$ was defined by scoring the lithologies with values ranging from o (higher rock strength) to 4 (lower rock strength). These classes were implemented starting from a tripartite classification proposed by Tiranti et al. $(2008,2014)$ and based on their potential to weather into clay or other fine minerals.

Considering the mapped area of a given bedrock lithology class $\left(A_{L i}\right)$ with respect to the basin area $\left(A_{B}\right)$, the index quantifying the strength lithology of each class at the basin scale $\left(S_{L B i}\right)$ can be expressed as:

$$
S_{L B_{i}}=\left(\frac{A_{L i}}{A_{B}}\right) \cdot S_{L_{i}}
$$

From the contribution of each class $\left(S_{L B i}\right)$, the Lithological Index $\left(i_{L}\right)$ can be given by:

$$
i_{L}=\sum S_{L B_{i}}
$$

The $i_{L}$ describes the susceptibility of the intact bedrock within a given basin on furnishing loose material that may be mobilized during debris flow events.

\subsubsection{Fracture network}

The fracture network of a rock mass, defined by 
the spatial arrangement of any type of fractures, including discrete surfaces and zones of opening fractures (joints) and faults, can lead to favourable conditions for debris flow generation (Kouli et al. 2010). Fractures affect surface material increasing the amount of loose debris from degradation of rock masses (Ferrero et al. 2016; Caselle et al. 2020a; Umili et al. 2020) and water circulation that induces hydraulic pressure along fracture planes. It is important to remember that lithology also has a major control on the development of fracture patterns.

Lineament extraction from remote sensing analysis is a useful and reliable tool (Tripathi et al. 2000; Jordan et al. 2005; Vaz et al. 2012; Bonetto et al. 2017; Umili et al. 2018) for mapping fracture network on outcrops at regional scale. In this study, a visual approach was adopted by drawing lineaments on aerial photos.

The lineament trend, obtained by remote survey, was evaluated by comparing the results with available data from classical geomechanical surveys (scan lines) performed by the authors in representative areas of each basin, in order to verify the reliability of the records. The fracture intensity (FI) (total trace length per unit area) of each analysed outcrop of a given lithology class was estimated as:

$$
F I_{i}=\frac{L_{i}}{A_{i}}
$$

where $L_{i}$ is the total trace length and $A_{i}$ is the surface of the investigated outcrop of a specific lithology class, identified from aerial photographs.

$F I_{i}$ was enhanced to include the relationship between fracture intensity and bedrock lithology in a new index $F I L_{i}$ (fracture intensity for each bedrock lithology):

$$
F I L_{i}=F I_{i} \cdot S_{L B_{i}}
$$

where $S_{L B i}$ is the strength lithology index defined in the previous section.

The total fracture index of the basin $\left(i_{F}\right)$ can be estimated by:

$$
i_{F}=\sum F I L_{i}
$$

Since $i_{F}$ is not dimensionless and can assume values higher than $I_{i j t h}$, it is scaled following the criteria proposed in Table 1.

\subsubsection{Quaternary deposits}

Most debris flow material has a metastable, loose, or high porosity structure (Hutchinson 1988) originating from discrete or distributed source areas, characterized by steep slopes. As a result of intense rainfall or snowmelt, these deposits become partially/ totally saturated and start to move when driving forces are greater than frictional forces (at some depth). Thus, debris availability, both within the source area and along the runout path, is one of the most important predisposing factors (Bovis and Jakob 1999).

Especially in the Alpine basins where types and distributions of deposits are derived from erosion, weathering and fall of bedrock are the result of the Quaternary geological evolution. Quaternary deposits and bedrock lithology can be considered as independent parameters since the former is related to potentially unstable volume and the latter can be related to the mechanical characteristics of the rock.

Types and spatial distributions of Quaternary deposits are obtained by geological mapping. A qualitative "strength" rating, $S_{\mathrm{D}}$ ranging from o to 4 , was attributed to each type of deposit on the basis of their distinctive textural features, type of matrix, and geotechnical behaviour.

As in bedrock lithology analysis, the mapped area of a given deposit $\left(A_{\mathrm{Di}}\right)$ and the basin area $\left(A_{\mathrm{B}}\right)$ were considered for defining the strength of a given deposit class at the basin scale $\left(S_{\mathrm{DBi}}\right)$ as:

$$
S_{D B_{i}}=\left(\frac{A_{D_{i}}}{A_{B}}\right) \times S_{D_{i}}
$$

Then, the influence of all the Quaternary deposits (iD) on predisposing debris flow events, was given by:

$$
i_{D}=\sum S_{D B_{i}}
$$

\subsubsection{Slope inclination}

Basin slope, and in particular channel bed slope, is one of the first parameters to analyse in the study of debris flow events since it amplifies the combined effects of many factors such as the intensity of climatic conditions, the weathering processes, and the internal geometry of geological formations (Rozos et al. 2008). This parameter is easy to obtain and can immediately reveal information about possible debris instabilities and flow formation (Rickenmann et al. 1993; Liu et al. 1994; D’Agostino 1996; Dine 1996;

Table $1 i_{\mathrm{F}}$ rating as a function of the density of fracturing.

\begin{tabular}{l|l|l|}
\hline Fracture network classes & $i_{\mathrm{F}}\left(\mathrm{km}^{-1}\right)$ & $i_{\mathrm{F}}$ Rating \\
\hline Weak & $\mathbf{0}-\mathbf{2}$ & $\mathbf{0}$ \\
\hline Moderate & $2-5$ & $\mathbf{1}$ \\
\hline Strong & $5-10$ & 2 \\
\hline Very Strong & $10-20$ & 3 \\
\hline Intense & $>\mathbf{2 0}$ & 4
\end{tabular}


Takahashi 2007).

Generally, debris flows are triggered where slopes range between $20^{\circ}$ and $45^{\circ}$ (Hungr et al. 2014) while for inclinations steeper than $45^{\circ}$, the debris is not present, or it has a negligible thickness. Accordingly, five different slope classes were distinguished and a qualitative "strength" rating $S_{\theta \mathrm{i}}$ ranging from o to 4 was attributed.

For each basin, the surface characterized by each class of slope $\left(A_{\mathrm{s} \theta}\right)$ was calculated. The slope index, IS, is given by:

$$
I S_{i}=\frac{A_{S \theta_{i}}}{A_{B}} \cdot S_{\theta_{i}}
$$

The weighted contribution of each slope classes within the whole basin can be expressed as:

$$
i_{S \theta}=\sum I S_{i}
$$

\subsubsection{Hydrographic network}

Excluding the amount of water derived directly from atmospheric events (including snow melt), the hydrographic network is a crucial predisposing factor in debris flow triggering. In a basin, second and third order streams greatly influence debris flow transportation, inducing erosional processes and, sporadically, local instabilities that increase the debris flow magnitude.

For these reasons, a hydrographic network index was proposed as follows:

$$
i_{H}=\frac{L_{1}+L_{2}}{A_{B}} \cdot \frac{L_{2}}{L_{1}}
$$

where $L_{1}$ and $L_{2}$ are the length of the principal and the tributary channels, respectively.

The first factor describes the density of the hydrographic network within the basin while the second term defines the relationship between the lengths of tributary streams and principal channels. High $i_{\mathrm{H}}$ values represent an intense hydrographic network inside the basin; on the other hand, $i_{\mathrm{H}}$ values close to o define basins where the principal channel is dominant compared to the tributary streams.

Since $i_{\mathrm{H}}$ is not dimensionless and can assume values higher than $I_{i j t h}$, it is scaled following the criteria proposed in Table 2.

Table $2 i_{\text {H }}$ rating as a function of the hydrographical network.

\begin{tabular}{|l|l|l|}
\hline Hydrographic network classes & $i_{\mathrm{F}}\left(\mathrm{km}^{-1}\right)$ & $i_{\mathrm{F}}$ Rating \\
\hline Weak & $0-2$ & $\mathrm{O}$ \\
\hline Moderate & $2-5$ & 1 \\
\hline Strong & $5-10$ & 2 \\
Very strong & $10-15$ & 3 \\
Intense & $>15$ & 4
\end{tabular}

\section{Results}

\subsection{RES Interaction matrix}

In complex geological problems, such as the definition of debris flow susceptibility areas, it is fundamental to define and quantify the mutual interactions of each factor. Thus, for the calculation of weighted coefficient and the definition of DfPI, a descriptive interaction matrix between the parameters is proposed (Table 3 ).

Using the ESQ method (Harrison and Hudson 2006), each mutual interaction of off-diagonal terms was scored with values ranging from $o$ (no interaction) to 4 (critical interaction) and the numerical coding is reported in Table 4.

By analyzing Table 4, it can be seen that slope and hydrographic network are the most interactive parameters $(C+E=19)$ while bedrock lithology is the less interactive $(C+E=13)$. On the other hand, the most dominant parameter is the Quaternary deposit $(C-E=14)$, while the least dominant parameter is the fracture network $(C-E=4)$. These results can also be analyzed in the $C-E$ diagram (Fig. 5), where the shape of the $C$ versus $E$ cluster, with respect to the $C=E$ line, defines the number of crucial parameters necessary for evaluating DfPI. Since $C-E$ data are perpendicular to the $C=E$ line, there is a small range of interaction intensity and a wide range in dominance between parameters. Thus, all five selected parameters are required for DfPI calculation.

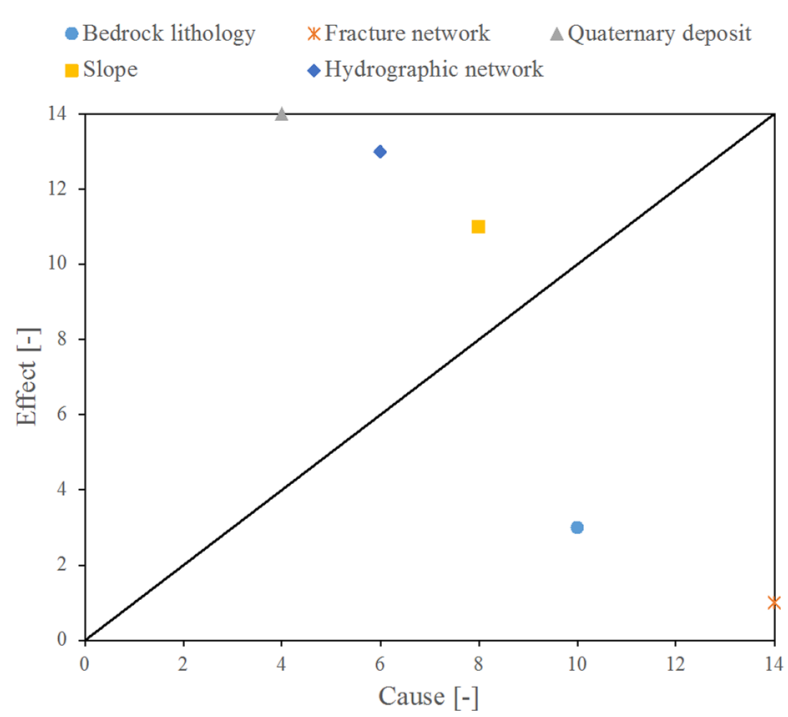

Fig. 5 Cause versus Effect diagram obtained from Rock Engineering System (RES) procedure. 
Table $35 \times 5$ interaction matrix applied to debris flow phenomena

\begin{tabular}{|c|c|c|c|c|}
\hline $\begin{array}{l}\text { Bedrock } \\
\text { lithology }\end{array}$ & $\begin{array}{l}\text { The type of substrate in } \\
\text { relation to its mineral- } \\
\text { petrographical } \\
\text { composition and strength } \\
\text { conditions, considering } \\
\text { the same stress state, will } \\
\text { affect the degree of } \\
\text { fracturing. }\end{array}$ & $\begin{array}{l}\text { The composition of the } \\
\text { substrate affects the } \\
\text { alterability of the rock } \\
\text { and therefore the } \\
\text { susceptibility to generate } \\
\text { debris, which can be } \\
\text { easily mobilized. }\end{array}$ & $\begin{array}{l}\text { The slope is the } \\
\text { morphological } \\
\text { expression of rock } \\
\text { weathering. Strength, } \\
\text { fabric and rock texture } \\
\text { affect slope morphology. }\end{array}$ & $\begin{array}{l}\text { Compositional and } \\
\text { textural features affect the } \\
\text { erodibility of the stream. } \\
\text { For this reason the } \\
\text { hydrographical network is } \\
\text { influenced. }\end{array}$ \\
\hline $\begin{array}{l}\text { Faulting and } \\
\text { structural } \\
\text { elements can } \\
\text { control } \\
\text { juxtaposition of } \\
\text { different types } \\
\text { of rock. }\end{array}$ & Fracture network & $\begin{array}{l}\text { Brittle deformation } \\
\text { influences the rock } \\
\text { fracturing, increasing the } \\
\text { rock weathering. These } \\
\text { processes increase the } \\
\text { availability of loose } \\
\text { material that change the } \\
\text { magnitude of the deposit. }\end{array}$ & $\begin{array}{l}\text { Highly fractured } \\
\text { substrates are subject to } \\
\text { alteration, erosion and } \\
\text { decrease of mechanical } \\
\text { properties (friction angle } \\
\text { and cohesion) with } \\
\text { consequent influence on } \\
\text { slopes (minor slopes). }\end{array}$ & $\begin{array}{l}\text { The presence of brittle } \\
\text { deformation affects the } \\
\text { erodibility and alterability } \\
\text { of the substrate, increasing } \\
\text { the erosive power of } \\
\text { streams. Moreover, fault } \\
\text { zones may allow the } \\
\text { formation of new stream. }\end{array}$ \\
\hline $\begin{array}{l}\text { Quaternary } \\
\text { deposits define } \\
\text { areal } \\
\text { distribution of } \\
\text { bedrock at } \\
\text { surface. }\end{array}$ & $\begin{array}{l}\text { No direct conditioning on } \\
\text { the development and } \\
\text { localization of fragile } \\
\text { structures. They protect } \\
\text { the fractured substrate } \\
\text { from the action of } \\
\text { atmospheric agents, } \\
\text { limiting the weathering } \\
\text { and decay of the } \\
\text { resistance parameters }\end{array}$ & Quaternary deposits & $\begin{array}{l}\text { Slopes on deposits have } \\
\text { different acclivity } \\
\text { depending on the types, } \\
\text { thickness and textural } \\
\text { characteristics of the } \\
\text { loose deposits that } \\
\text { characterize them }\end{array}$ & $\begin{array}{l}\text { Type, thickness and } \\
\text { textural characteristics of } \\
\text { the deposits influence the } \\
\text { morphology around the } \\
\text { stream. }\end{array}$ \\
\hline No influence & No influence & $\begin{array}{l}\text { The slope affects the } \\
\text { presence, stability and } \\
\text { thickness of any deposits }\end{array}$ & Slope & $\begin{array}{l}\text { The slope affects the } \\
\text { energy of the watercourse } \\
\text { and the erosive power }\end{array}$ \\
\hline No influence & No influence & $\begin{array}{l}\text { The channel can } \\
\text { determine the } \\
\text { accumulation or } \\
\text { movement of the } \\
\text { deposits by changing the } \\
\text { distribution and textural } \\
\text { characteristics of } \\
\text { deposits. }\end{array}$ & $\begin{array}{l}\text { Depending on the energy } \\
\text { of the watercourse and } \\
\text { its erosive capacity, the } \\
\text { hydrographic network } \\
\text { can reshape the slope }\end{array}$ & Hydrographic network \\
\hline
\end{tabular}

Table 4 Matrix of binary interactions coded for basins subjected to debris flow event

\begin{tabular}{|c|c|c|c|c|c|c|c|c|c|c|c|}
\hline & 1 & 2 & 3 & 4 & 5 & $C$ & $C+E$ & $C-E$ & Parameters & $\begin{array}{l}{[(C+E) /} \\
\left.\left(\Sigma I_{i j}+\Sigma I_{j i}\right)\right] \times 100\end{array}$ & $a_{i}$ \\
\hline 1 & $\begin{array}{l}\text { Bedrock } \\
\text { lithology }\end{array}$ & 1 & 4 & 2 & 3 & 10 & 13 & 10 & $\begin{array}{l}\text { Bedrock } \\
\text { lithology }\end{array}$ & 15 & 3.87 \\
\hline 2 & 3 & $\begin{array}{l}\text { Fracture } \\
\text { network }\end{array}$ & 3 & 4 & 4 & 14 & 15 & 14 & $\begin{array}{l}\text { Fracture } \\
\text { network }\end{array}$ & 18 & 4.46 \\
\hline 3 & o & O & $\begin{array}{l}\text { Quaternary } \\
\text { deposits }\end{array}$ & 2 & 2 & 4 & 18 & 4 & $\begin{array}{l}\text { Quaternary } \\
\text { deposits }\end{array}$ & 21 & $5 \cdot 36$ \\
\hline 4 & O & o & 4 & Slope & 4 & 8 & 19 & 8 & Slope & 23 & 5.65 \\
\hline 5 & O & o & 3 & 3 & $\begin{array}{l}\text { Hydrographic } \\
\text { network }\end{array}$ & 6 & 19 & 6 & $\begin{array}{l}\text { Hydrographic } \\
\text { network }\end{array}$ & 23 & 5.65 \\
\hline$E$ & 3 & 1 & 14 & 11 & 13 & 42 & 84 & & & 100 & \\
\hline
\end{tabular}

\subsection{Numerical quantification of the $P_{\text {ik }}$ indexes for DfPI evaluation}

Following the procedure described in Section 3.2, five $P_{i k}$ indexes were calculated for each predisposing factor, aimed at defining the DfPI for each analysed basin.

\subsubsection{Bedrock lithology}

The lithological indexes $\left(i_{\mathrm{L}}\right)$ for each basin are listed in Table 5 . The obtained $i_{L}$ values clearly reflect the relationship between bedrock conditions and basin extent (see Fig. 2a): since only the upper sectors of each selected basin are mainly characterized by 
Table 5 Lithological indexes for each analysed basin

\begin{tabular}{|c|c|c|c|c|c|c|}
\hline \multirow{2}{*}{$S_{L}$ rating } & \multirow{2}{*}{ Bedrock Lithology Classes } & Basins & GERONDA & SECCO & SEGURET & CHAMPEIRON \\
\hline & & $A_{B}\left(\mathrm{~km}^{2}\right)$ & 3.66 & 5.93 & 9.65 & 2.84 \\
\hline \multirow{3}{*}{ O } & \multirow{3}{*}{ Quartzite (QZ) } & $A_{L}\left(\mathrm{~km}^{2}\right)$ & 0.01 & 0.07 & 0.13 & 0.00 \\
\hline & & $A_{L} / A_{B}(-)$ & 0.00 & 0.01 & 0.01 & 0.00 \\
\hline & & $S_{L B}(-)$ & 0.00 & 0.00 & 0.00 & 0.00 \\
\hline \multirow{3}{*}{1} & \multirow{3}{*}{ Quartz micaschist, Gneiss (MG) } & $A_{L}\left(\mathrm{~km}^{2}\right)$ & 0.95 & 1.89 & 0.04 & 0.03 \\
\hline & & $A_{L} / A_{B}(-)$ & 0.26 & 0.32 & 0.00 & 0.01 \\
\hline & & $S_{L B}(-)$ & 0.26 & 0.32 & 0.00 & 0.01 \\
\hline \multirow{3}{*}{2} & \multirow{3}{*}{ Dolomitic Limestone Rock (DL) } & $A_{L}\left(\mathrm{~km}^{2}\right)$ & 0.00 & 0.76 & 0.96 & 0.35 \\
\hline & & $A_{L} / A_{B}(-)$ & 0.00 & 0.13 & 0.10 & 0.12 \\
\hline & & $S_{L B}(-)$ & 0.00 & 0.26 & 0.20 & 0.25 \\
\hline \multirow{3}{*}{3} & \multirow{3}{*}{$\begin{array}{l}\text { Calcschist - Calcareous micaschist } \\
\text { (CM) }\end{array}$} & $A_{L}\left(\mathrm{~km}^{2}\right)$ & 0.00 & 0.14 & 0.54 & 0.07 \\
\hline & & $A_{L} / A_{B}(-)$ & 0.00 & 0.02 & 0.06 & 0.02 \\
\hline & & $S_{L B}(-)$ & 0.00 & 0.07 & 0.17 & 0.07 \\
\hline \multirow{3}{*}{4} & \multirow{3}{*}{$\begin{array}{l}\text { Gypsum and carbonate breccias } \\
\text { (GB) }\end{array}$} & $A_{L}\left(\mathrm{~km}^{2}\right)$ & 0.00 & 0.02 & 0.19 & 0.00 \\
\hline & & $A_{L} / A_{B}(-)$ & 0.00 & 0.00 & 0.02 & 0.00 \\
\hline & & $S_{L B}(-)$ & 0.00 & 0.01 & 0.08 & 0.00 \\
\hline$i_{\mathrm{L}}$ & & & 0.26 & 0.66 & 0.45 & 0.33 \\
\hline
\end{tabular}

Note: $A_{B}$ : Basin Area, $A_{L}$ : Lithology surface, $S_{L B}$ : strength lithology at the basin scale, $i_{L}$ : Lithological Index

outcropping portions of a certain lithological class (mostly with high strength quality), the final influence of this parameter is quite low (lower than one for each basin).

\subsubsection{Fracture network}

Most of the lineaments are NW-SE, NE-SW or N$\mathrm{S}$ trending with various intensity ( $\mathrm{Li}$ ), in good agreement with the regional geological setting and with the results of available mesostructural data (Malusà and Mosca 2002; Polino et al. 2002; Malusà 2004). In gypsum and carbonate breccias (GB), lineaments have not been recognized due to the features of the outcrop surface. However, in this case, stability and alterability of the rock mass is dependent on the strength of the rock matrix and the very low mechanical quality (Caselle et al. 2019).

Fig. 6 shows the fracture network detection applied to Geronda Basin: the red lines represent the recognized geological lineaments. The same procedure was performed on each case study. The values of fracture networ $\mathrm{k}$ indexes are listed in Table 6.

\subsubsection{Quaternary deposits}

Quaternary deposit index values are listed in Table 7. According to Fig. 2b and in field observations, the Quaternary deposit indexes are quite high compared to bedrock lithology indexes (see Table 5) due to the significant presence of loose debris along the basin flanks.

\subsubsection{Slope inclination}

Fig. 7 shows the slope map of the four watersheds obtained from the $5 \times 5 \mathrm{~m}$ resolution DEM.

The results of spatial analysis and index values defined for each basin are listed in Table 8. In general, all the basins have high slope index values (greater than 3 ) as the majorit y of the watersheds have slopes between $31^{\circ}$ and $45^{\circ}$. However, the Champeiron basin exhibits the lowest value of $i_{s \theta}$ : in fact, only the basin crown has a steep inclination $\left(>45^{\circ}\right)$ and gentle slopes in the remainder of the basin.

\subsubsection{Hydrographic network}

Hydrographic patterns were classified into principal and tributary channels (Fig. 8) and their lengths were measured on the DEM. Table 9 summarizes the results obtained by hydrographic pattern analysis; a correspondent hydrographic network index for each basin was obtained by using Eq. (12).

Comparing Fig. 8 and Table 9, it can be highlighted that Rio Secco and Rio Seguret basins show the highest $i_{H}$ values due to the significant development of lower order drainage systems, which cover most of the peripheral areas of the basins. On the other hand, in the Geronda and Champeiron basins the main channel path is dominant compared to the tributary streams.

\subsection{DfPI evaluation}

DfPI was evaluated for each basin (Table 10) by using Eq. (1). This index, which varies between $\mathrm{o}$ and 100, can be used as an indicator of debris flow 
susceptibility for a given basin based on geological and geomorphological information. To describe the debris flow susceptibility in qualitative terms, the modified Brabb's classification (1987) is used.
DfPI and susceptibility class are also compared with recorded events and the frequency for each basin. Table 9 highlights that Secco and Seguret basin have a very high susceptibility to debris flow events while

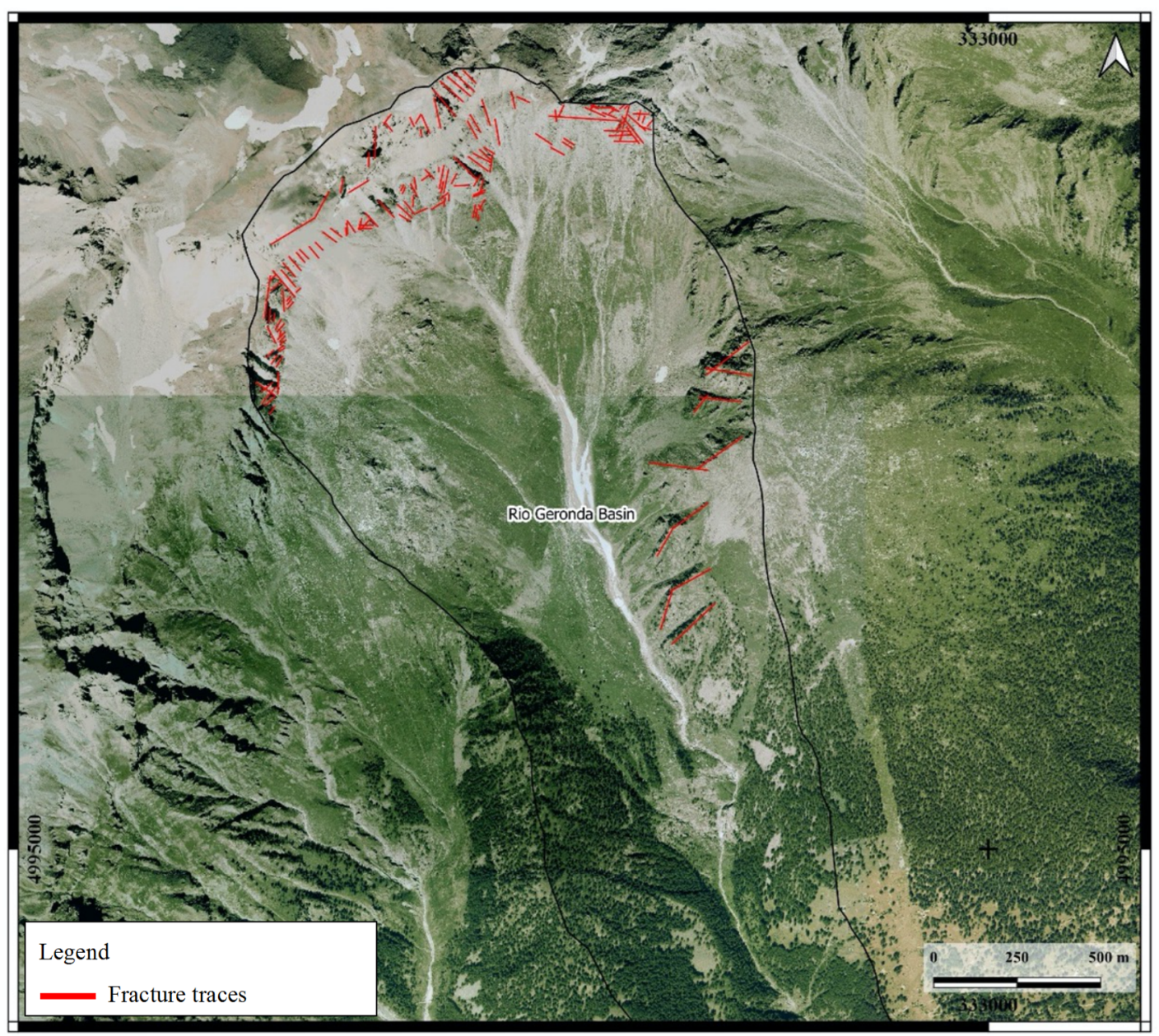

Fig. 6 Example of fracture trend identification on aerial photos (c) Google Maps). SR: WGS84/UTM zone 32N.

Table 6 Fracture network indexes for each analysed basin

\begin{tabular}{|c|c|c|c|c|c|}
\hline Fracture Network Classes & Basins & GERONDA & SECCO & SEGURET & CHAMPEIRON \\
\hline \multirow[t]{4}{*}{ 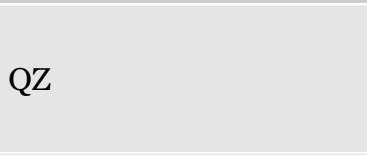 } & $L_{i}(\mathrm{~km})$ & & & 1.317 & \\
\hline & $A_{i}\left(\mathrm{~km}^{2}\right)$ & & & 0.162 & \\
\hline & FI $\left(\mathrm{km}^{-1}\right)$ & & & 8.130 & \\
\hline & FIL & & & 8.130 & \\
\hline \multirow{4}{*}{ MG } & $L_{i}(\mathrm{~km})$ & 10.408 & $5 \cdot 368$ & & \\
\hline & $A_{i}\left(\mathrm{~km}^{2}\right)$ & 0.528 & 1.197 & & \\
\hline & FI $\left(\mathrm{km}^{-1}\right)$ & 19.712 & 4.485 & & \\
\hline & FIL & 5.100 & 1.432 & & \\
\hline \multirow{4}{*}{ DL } & $L_{i}(\mathrm{~km})$ & & 6.387 & 3.667 & 2.464 \\
\hline & $A_{i}\left(\mathrm{~km}^{2}\right)$ & & 0.659 & 0.345 & 0.238 \\
\hline & FI $\left(\mathrm{km}^{-1}\right)$ & & 9.692 & 10.629 & 10.353 \\
\hline & FIL & & 2.484 & 2.110 & 2.566 \\
\hline$i_{F}$ & & 5.100 & 3.917 & 2.110 & 2.566 \\
\hline$i_{F}$ rating & & & & 1 & \\
\hline
\end{tabular}

Notes: $L_{i}$ : total trace length; $A_{i}$ : surface of the investigated outcrop of a specific lithology class; FI: fracture intensity; FIL: fracture intensity for each bedrock lithology. 
Table 7 Quaternary deposit indexes for each analysed basin

\begin{tabular}{|c|c|c|c|c|c|c|c|}
\hline \multirow{2}{*}{$\begin{array}{l}\text { SD } \\
\text { Rating }\end{array}$} & \multirow{2}{*}{$\begin{array}{l}\text { Quaternary } \\
\text { deposit classes }\end{array}$} & \multirow{2}{*}{ Description } & Basins & GERONDA & SECCO & SEGURET & CHAMPEIRON \\
\hline & & & $A_{B}\left(\mathrm{~km}^{2}\right)$ & 3.66 & 5.93 & 9.65 & 2.84 \\
\hline \multirow[b]{3}{*}{ O } & \multirow[b]{3}{*}{$\begin{array}{l}\text { Talus deposits } \\
\text { (TQ) }\end{array}$} & \multirow{3}{*}{$\begin{array}{l}\text { Openwork and partially } \\
\text { openwork deposits made up } \\
\text { of angular clasts and blocks of } \\
\text { prevailing quartzite, quartz- } \\
\text { micaschist, gneiss or marble } \\
\text { and scanty sandy-silty and } \\
\text { sandy-gravelly matrix }\end{array}$} & $A_{D}\left(\mathrm{~km}^{2}\right)$ & 0.447 & 0.19 & 0 & 0.396 \\
\hline & & & $A_{D} / A_{B}(-)$ & 0.122 & 0.032 & 0.000 & 0.139 \\
\hline & & & $S_{D B}(-)$ & 0.000 & 0.000 & 0.000 & 0.000 \\
\hline \multirow[b]{3}{*}{1} & \multirow[b]{3}{*}{$\begin{array}{l}\text { Talus deposits } \\
\text { (TC) }\end{array}$} & \multirow{3}{*}{$\begin{array}{l}\text { Openwork and partially } \\
\text { openwork deposits made up } \\
\text { of angular clasts and blocks of } \\
\text { prevailing calcschist or } \\
\text { calcareous micaschists and } \\
\text { scanty sandy-silty and sandy- } \\
\text { gravelly matrix }\end{array}$} & $A_{D}\left(\mathrm{~km}^{2}\right)$ & o & o & 0.741 & o \\
\hline & & & $A_{D} / A_{B}(-)$ & 0.000 & 0.000 & 0.077 & 0.000 \\
\hline & & & $S_{D B}(-)$ & 0.000 & 0.000 & 0.077 & 0.000 \\
\hline \multirow{3}{*}{2} & \multirow{3}{*}{$\begin{array}{l}\text { Glacial } \\
\text { deposits (GD) }\end{array}$} & \multirow{3}{*}{$\begin{array}{l}\text { Chaotic deposits consisting of } \\
\text { heterometric unsorted clasts } \\
\text { and blocks embedded in silty- } \\
\text { sandy matrix }\end{array}$} & $A_{D}\left(\mathrm{~km}^{2}\right)$ & 0.465 & 0.503 & 1.435 & 0.231 \\
\hline & & & $A_{D} / A_{B}(-)$ & 0.127 & 0.085 & 0.149 & 0.081 \\
\hline & & & $S_{D B}(-)$ & 0.254 & 0.170 & 0.297 & 0.163 \\
\hline \multirow[b]{3}{*}{3} & \multirow[b]{3}{*}{$\begin{array}{l}\text { Landslides } \\
\text { deposits (LD) }\end{array}$} & \multirow{3}{*}{$\begin{array}{l}\text { Chaotic deposits made up of } \\
\text { heterometric clasts and } \\
\text { blocks with sandy-silty matrix } \\
\text { in variable proportions; rocky } \\
\text { accumulations made up of } \\
\text { loosened portions of bedrock, } \\
\text { locally of large dimensions }\end{array}$} & $A_{D}\left(\mathrm{~km}^{2}\right)$ & 0.106 & 0.076 & 1.069 & o \\
\hline & & & $A_{D} / A_{B}(-)$ & 0.029 & 0.013 & 0.111 & 0.000 \\
\hline & & & $S_{D B}(-)$ & 0.087 & 0.038 & 0.332 & 0.000 \\
\hline \multirow{3}{*}{4} & \multirow{4}{*}{$\begin{array}{l}\text { Eluvio- } \\
\text { colluvial } \\
\text { deposits (CD) }\end{array}$} & \multirow{4}{*}{ Loose fine material } & $A_{D}\left(\mathrm{~km}^{2}\right)$ & 1.686 & 2.283 & 4.555 & 1.765 \\
\hline & & & $A_{D} / A_{B}(-)$ & 0.461 & 0.385 & 0.472 & 0.621 \\
\hline & & & $S_{D B}(-)$ & 1.843 & 1.540 & 1.888 & 2.486 \\
\hline $\mathrm{iD}_{\mathrm{D}}$ & & & & 2.184 & 1.748 & 2.595 & 2.649 \\
\hline
\end{tabular}

Notes: $A_{B}$ : Basin Area; $A_{D}$ : Deposit surface; $S_{D B}$ : strength of a given deposit class at the basin scale; $i_{D}$ : Deposit Index

Geronda and Champeiron exhibit a high susceptibility to this phenomenon. These results are partially mirrored by the number of recorded events in each basin: in fact, the Secco basin exhibits the highest DfPI value and the highest number of recorded events. On the contrary, Champeiron basin has the lowest DfPI value and the lowest number of recorded debris flow events. Geronda and Seguret have almost the same number of recorded events (respectively 7 and 5) but quite different DfPI (respectively 48 and 55), which ranks them in two different susceptibility classes (respectively V and VI).

This difference can be explained by the frequency of events in Seguret basin which is double that of Geronda.

\section{Discussion}

The presented results show a good match between the forecasted susceptibility indexes (DfPI) and the occurrence of debris flow events in the analyzed basins. In general, a high value of susceptibility index corresponds to a significant number of debris flow events. The Rio Seguret basin does not reflect the global trend of the other basins but provides an interesting starting point for further discussions on the nature of data archives. The available datasets provide only the most relevant events (those that resulted in damages to local infrastructures and/or buildings), neglecting events with no damages. The main problem in the use of such a dataset is the reliability of the number and frequency of the events. Most of the events that happened in uninhabited areas were usually not recorded, so it is difficult to compare data from one basin to another. Consequently, the lack of a complete and reliable inventory is the main limitation for validation of the results. 


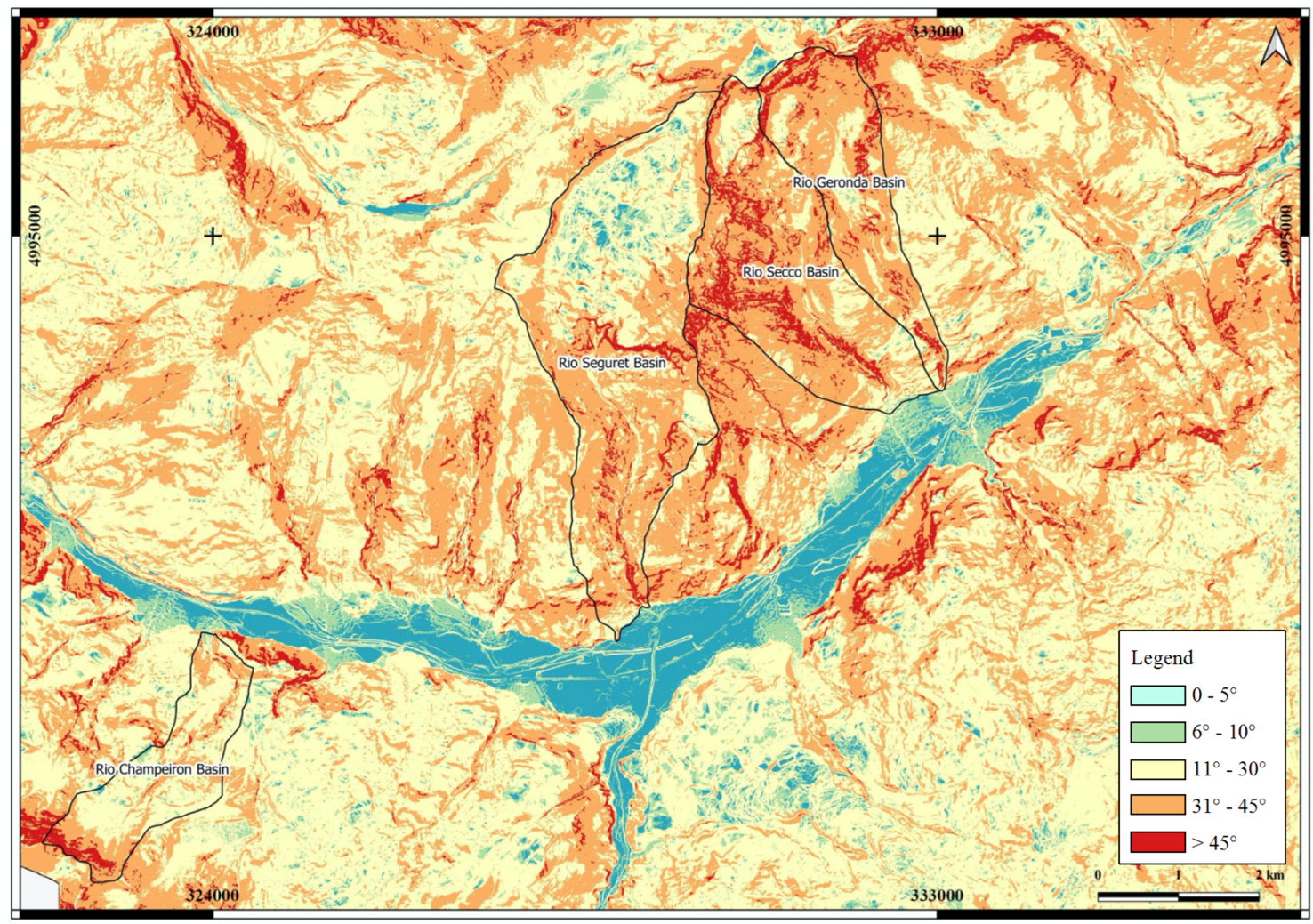

Fig. 7 Slope map of the study area using 5 m resolution DEM. SR:WGS84/UTM zone 32N.

Table 8 Slope inclination indexes for each analysed basin

\begin{tabular}{|c|c|c|c|c|c|c|}
\hline \multirow{2}{*}{$\begin{array}{l}\text { Slope } \\
\text { inclination Classes }\end{array}$} & \multirow{2}{*}{$\begin{array}{l}S_{\theta} \\
\text { Rating }\end{array}$} & Basins & GERONDA & SECCO & SEGURET & CHAMPEIRON \\
\hline & & $A_{B}\left(\mathrm{~km}^{2}\right)$ & 3.66 & 5.93 & 9.65 & 2.84 \\
\hline \multirow{3}{*}{$0-5$} & \multirow{3}{*}{0} & $A_{S \theta}\left(\mathrm{km}^{2}\right)$ & 0.000 & 0.000 & 0.000 & 0.000 \\
\hline & & $A_{S \theta} / A_{B}(-)$ & 0.000 & 0.000 & 0.000 & 0.000 \\
\hline & & $S \theta(-)$ & 0.00 & 0.00 & 0.00 & 0.00 \\
\hline \multirow{3}{*}{$6-10$} & \multirow{3}{*}{1} & $A_{S \theta}\left(\mathrm{km}^{2}\right)$ & 0.035 & 0.061 & 0.709 & 0.098 \\
\hline & & $A_{S \theta} / A_{B}(-)$ & 0.010 & 0.010 & 0.073 & 0.035 \\
\hline & & $S \theta(-)$ & 0.01 & 0.01 & 0.07 & 0.03 \\
\hline \multirow{3}{*}{$>45$} & \multirow{3}{*}{2} & $A_{S \theta}\left(\mathrm{km}^{2}\right)$ & 0.509 & 1.084 & 0.502 & 0.172 \\
\hline & & $A_{s \theta} / A_{B}(-)$ & 0.139 & 0.183 & 0.052 & 0.061 \\
\hline & & $S \theta(-)$ & 0.28 & 0.37 & 0.10 & 0.12 \\
\hline \multirow{3}{*}{$11-30$} & \multirow{3}{*}{3} & $A_{S \theta}\left(\mathrm{km}^{2}\right)$ & 0.877 & 1.323 & 3.961 & 1.670 \\
\hline & & $A_{S \theta} / A_{B}(-)$ & 0.240 & 0.223 & 0.410 & 0.588 \\
\hline & & $S \theta(-)$ & 0.72 & 0.67 & 1.23 & 1.76 \\
\hline \multirow{3}{*}{$31-45$} & \multirow{3}{*}{4} & $A_{S \theta}\left(\mathrm{km}^{2}\right)$ & 2.235 & 3.464 & 4.481 & 0.900 \\
\hline & & $A_{S \theta} / A_{B}(-)$ & 0.611 & 0.584 & 0.464 & 0.317 \\
\hline & & $S_{\theta}(-)$ & 2.44 & 2.34 & 1.86 & 1.27 \\
\hline$i_{S \theta}$ & & & 3.45 & 3.38 & 3.27 & 3.19 \\
\hline
\end{tabular}

Notes: $A_{B}$ : Basin Area; $A_{S \theta}$ : surface characterized by each class of slope; $S \theta$ : qualitative "strength" rating; $i_{S \theta}$ : Slope Index.

Table 9 Hydrographic network indexes for each studied basin

\begin{tabular}{|l|l|l|l|l|}
\hline Indexes & GERONDA & SECCO & SEGURET & CHAMPEIRON \\
\hline$L_{1}(\mathrm{~km})$ & 5.575 & 4.559 & 7.801 & 4.667 \\
\hline$L_{2}(\mathrm{~km})$ & 4.525 & 18.552 & 24.689 & 4.621 \\
\hline$i_{\mathrm{H}}\left(\mathrm{km}^{-1}\right)$ & 2.240 & 15.859 & 10.656 & 3.238 \\
\hline$i_{\mathrm{H}}$ rating $(-)$ & 1.000 & 4.000 & 3.000 & 1.000 \\
\hline
\end{tabular}

Notes: $L_{1}$ : length of the principal channels; $L_{2}$ : length of the tributary channels; $i_{H}$ : hydrographic network index. 


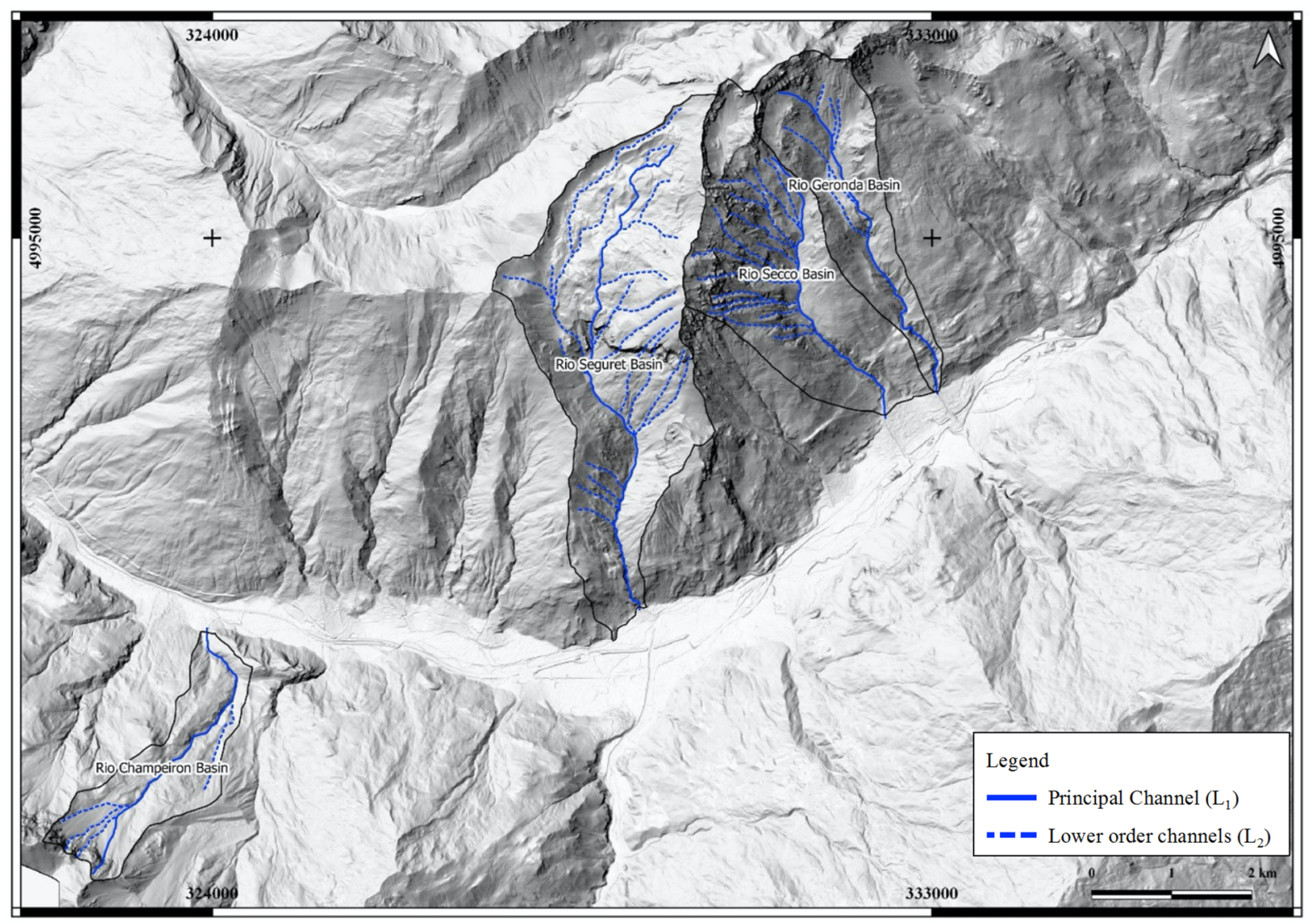

Fig. 8 Hydrographic pattern map of the study area developed using $5 \mathrm{~m}$ resolution DEM. SR: WGS84/UTM zone 32N.

Table 10 Debris flow Propensity Index (DfPI) indexes evaluated for each basin

\begin{tabular}{|c|c|c|c|c|c|c|c|c|c|c|}
\hline \multicolumn{2}{|l|}{ DfPI } & \multirow{3}{*}{$\begin{array}{l}\text { O-1 } \\
\text { I } \\
\text { None }\end{array}$} & \multirow{3}{*}{\begin{tabular}{|l}
$2-8$ \\
II \\
Very low
\end{tabular}} & \multirow{3}{*}{$\begin{array}{l}9-25 \\
\text { III } \\
\text { Low }\end{array}$} & \multirow{3}{*}{$\begin{array}{l}\text { 26-42 } \\
\text { IV } \\
\text { Medium }\end{array}$} & \multirow{3}{*}{$\begin{array}{l}43-53 \\
\text { V } \\
\text { High }\end{array}$} & \multirow{3}{*}{$\begin{array}{l}54-70 \\
\text { VI } \\
\text { Very High }\end{array}$} & \multirow{3}{*}{$\begin{array}{l}71-100 \\
\text { VII } \\
\text { Extreme }\end{array}$} & \multirow{3}{*}{$\begin{array}{l}\text { Recorded } \\
\text { events } \\
(1728-2015)\end{array}$} & \multirow{3}{*}{$\begin{array}{l}\text { Frequency } \\
\text { (\# event/year) }\end{array}$} \\
\hline Susce & ibility classes & & & & & & & & & \\
\hline wusect & 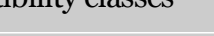 & & & & & & & & & \\
\hline \multirow{4}{*}{ Basin } & GERONDA & & & & & 48 & & & 7 & 21 \\
\hline & SECCO & & & & & & 58 & & 12 & 24 \\
\hline & SEGURET & & & & & & 55 & & 5 & 44 \\
\hline & CHAMPEIRON & & & & & 44 & & & 3 & 26 \\
\hline
\end{tabular}

The proposed methodology can be applied to different scales, from regional to local depending on the detail of the available datasets. In this preliminary study, a single value of DfPI representing the average susceptibility of the entire basin was evaluated. At this stage, a proper susceptibility mapping was not possible due to the lack of information about source debris flow location and the medium-low resolution of the the official geological map of Italy (CARG map in scale 1:50000). Further studies based on comparison of historical images and analysis of other landslide inventory, will be made for developing and validating a forecasting susceptibility map of the study area. Quantification of the parameters related to geological features of the basins (bedrock lithology, unconsolidated quaternary deposits, and fracture network) could benefit from subsequent field investigations and more detailed maps. The same consideration can be extended to DEM resolution for slope inclination and hydrographic pattern determination.

Regarding Eqs. (4) and (9), both the bedrock lithology index $\left(i_{L}\right)$ and the Quaternary deposit index $\left(i_{D}\right)$ influence the basin susceptibility index based on their presence in the basin and their strength quality. It is important to underline that these indexes intrinsically include the areal distribution (within the basin) of all bedrock lithologies and Quaternary deposits. For each selected basin, the $i_{L}$ values are very low (0-1) due to both the limited areal distribution of the bedrock with respect to Quaternary deposits, and the minimal influence of lithologies due 
to the prevalence and strength of bedrock (lower $\mathrm{S}_{\mathrm{L}}$ rating). With Quaternary deposits, the $i_{D}$ values are higher (1-3) due to their widespread extent and prevalence, in some basins, of deposits geotechnically poor and less stable (higher $S_{D}$ ). Therefore, the sum of $i_{L}$ and $i_{D}$ index can be considered as a "basin compositional index" that provides information on the geological order of the whole basin.

\section{Conclusions}

This paper suggests a quantitative, rapid, and low-cost methodology for debris flow susceptibility analysis based on open-access geodatabases. Five environmental predisposing factors (bedrock lithology, fracture network, unconsolidated Quaternary deposits, slope inclination and hydrographic network) were selected and indexed, and their mutual interactions quantified using the Rock Engineering System (RES) methodology.

RES methodology was used to quantify the mutual interaction among the five parameters, and once normalized by the overall interactivity of the system, provided further indications on their importance in debris flow susceptibility. An interaction matrix was developed, and its off-diagonal terms were scored using ESQ method. The interaction matrix is a universal tool since it is independent of the type and characteristic of the basin: for instance, other parameters (such as land use) may be considered without changing the methodological approach. Furthermore, the interaction matrix allows the model designer to include mechanisms not considered in other susceptibility methodologies.

For each parameter, an index $\left(P_{i k}\right)$ was proposed to quantitatively define the weight of the parameter on the debris flow susceptibility, based on its spatial distribution in the watershed. These indexes, coupled with the interaction matrix, result in the DfPI at the basin scale. DfPI is a weighted average of the dominant landslide predisposing parameters and allows for the identification of the main problematic basins that require further detailed field investigations.

Performance of this methodology was tested in four basins, with debris flow activity over several years, in the Upper Susa Valley (NW Italian Alps).
The DfPI results accurately represent the archived debris flow inventory both in terms of number and frequency of the recorded events.

The results are encouraging, but further research and modelling is needed in order to implement the matrix with new predisposing factors, and by increasing the number of test sites for better methodology calibration.

This methodology is a first screening for debris flow susceptibility of large areas. This methodology utilizes available and open-access data and meets the needs of authorities for land use management and planning. This methodology is appropriate for both small to medium and large-scale debris flow susceptibility areas.

Therefore, as a general conclusion, this research would like to emphasize the need for available geodatabases for scientists and public institutions in geo-environmental studies and projects, sharing data, using a standard vocabulary.

\section{Acknowledgements}

Authors want to thank the three anonymous reviewers and the Editor for the precious and constructive advice that helped to improve the paper. A special thanks to Dr. Laurie Kurilla for the English revision of the paper. The authors received no financial support for the research and authorship. Open access funding was provided by Università degli Studi di Torino within the CRUI-CARE Agreement.

Open Access This article is licensed under a Creative Commons Attribution 4.0 International License, which permits use, sharing, adaptation, distribution and reproduction in any medium or format, as long as you give appropriate credit to the original author(s) and the source, provide a link to the Creative Commons licence, and indicate if changes were made. The images or other third party material in this article are included in the article's Creative Commons licence, unless indicated otherwise in a credit line to the material. If material is not included in the article's Creative Commons licence and your intended use is not permitted by statutory regulation or exceeds the permitted use, you will need to obtain permission directly from the copyright holder. To view a copy of this licence, visit http://creativecommons.org/licenses/by/4.0/. 


\section{References}

ARPA PIEMONTE (2011) Sistema informativo dei fenomeni franosi in Piemonte (SIFRAP).

http://www.arpa.piemonte.it/approfondimenti/temiambientali/geologia-e-dissesto/bancadatiged/sifrap (Accessed on 26 March 2021), (in Italian language)

Ayalew L, Yamagishi H, Marui H, Kanno T (2005) Landslides in Sado Island of Japan: Part II. GIS-based susceptibility mapping with comparisons of results from two methods and verifications. Eng Geol 81:432-445.

https://doi.org/10.1016/j.enggeo.2005.08.004

Bonetto S, Facello A, Umili G (2017) A new application of curvatool semi-automatic approach to qualitatively detect geological lineaments. Environ Eng Geosci 23:179-190. https://doi.org/10.2113/gseegeosci.23.3.179

Bovis MJ, Jakob M (1999) The role of debris supply conditions in predicting debris flow activity. Earth Surf Process Landf 24:1039-1054. https://doi.org/10.1002/(SICI)10969837(199910)24:11<1039::AID-ESP29>3.0.CO;2-U

Brabb EE (1987) Innovative approaches to landslide hazard and risk mapping. Int J Rock Mech Min Sci Geomech Abstr 24:A16.

https://doi.org/10.1016/0148-9062(87)91363-5

Calligaris C, Zini L (2012) Debris Flow Phenomena: A Short Overview? In: Earth Sciences Imran Ahmad Dar, IntechOpen, https://doi.org/10.5772/29786

Carrara A, Guzzetti F, Cardinali M, Reichenbach P (1999) Use of GIS technology in the prediction and monitoring of landslide hazard. Nat Hazard 20:117-135

Cascini L, Bonnard C, Corominas J, et al. (2005) Landslide hazard and risk zoning for urban planning and developmentstate of the art report. In: Hungr, Fell, Couture, and Eberhardt (eds.), Landslide Risk Management, Proceeding of the International Conference on Landslide Risk Management, Vancouver, Canada. A.A. Balkema Publishers, Taylor \& Francis Group, London. pp 199-235.

Caselle C, Bonetto S, Vagnon F, Costanzo D (2019) Dependence of macro mechanical behaviour of gypsum on micro-scale grain-size distribution. Geotech Lett 9:1-9. https://doi.org/10.1680/jgele.18.00206

Caselle C, Bonetto S, Costanzo D (2020) Crack coalescence and strain accommodation in gypsum rock. Frat ed Integrita Strutt 14:247-255. https://doi.org/10.3221/IGF-ESIS.52.19

Corominas J, van Westen C, Frattini P, et al. (2014) Recommendations for the quantitative analysis of landslide risk. Bull Eng Geol Environ 73:209-263. https://doi.org/10.1007/s10064-013-0538-8

Coussot P, Meunier M (1996) Recognition, classification and mechanical description of debris flows. Earth-Science Rev 40:209-227. https://doi.org/10.1016/0012-8252(95)00065-8

Cruden DM, Varnes DJ (1996) Landslide types and processes. Spec Rep - Natl Res Counc Transp Res Board 247:36-75

Dal Piaz GV, Gianotti F, Monopoli B, et al. (2010) Note illustrative della Carta Geologica d'Italia alla scala 1: 50.0oo. (In Italian)

Dal Piaz GV (2010) The Italian Alps: A journey across two centuries of Alpine geology. J. Virtual Explor. 36

D’Agostino V, Cerato M, Coali R (1996) Il trasporto solido di eventi estremi nei torrenti del Trentino Orientale. In International Symposium Interpraevent. Publication No. 1. Garmisch-Partenkirchen, Germany. pp 377-386. (In Italian)

Dine V (1996) Debris Flow Control Structures for Forest Engineering Debris Flow Control Structures. Br Columbia

Ferrero AM, Umili G, Vagnon F (2016) Analysis of discontinuity data obtained with remote sensing tools to generate input for
EC7 design. In: Rock Mechanics and Rock Engineering: From the Past to the Future. pp 1115-1120

Glade T, Elverfeldt K (2005) MultiRISK: an innovative concept to model natural risks. In: Hungr, Fell, Couture, and Eberhardt (eds.), Landslide Risk Management, Proceeding of the International Conference on Landslide Risk Management, Vancouver, Canada. A.A. Balkema Publishers, Taylor \& Francis Group, London. pp 551-555.

Guzzetti F, Carrara A, Cardinali M, Reichenbach P (1999) Landslide hazard evaluation: A review of current techniques and their application in a multi-scale study, Central Italy. Geomorph 31(1-4):181-216

Harrison JP, Hudson JA (2006) Comprehensive hazard identification in rock engineering using interaction matrix mechanism pathways. In: Proceedings of the 41st U.S. Rock Mechanics Symposium (USRMS), Golden, Colorado pp 11441152.

Hungr O, Leroueil S, Picarelli L (2014) The Varnes classification of landslide types, an update. Landslides 11:167-194. https://doi.org/10.1007/s10346-013-0436-y

Hutchinson JN (1988) General report: morphological and geotechnical parameters of landslides in relation to geology and hydrogeology. Landslides Proc 5th Symp Lausanne 1: $3^{-}$ 35 .

https://doi.org/10.1016/0148-9062(89)90310-0

Iverson RM (1997) The physics of debris flows. Rev Geophys 35:245-296.

https://doi.org/10.1029/97RGoo426

Jakob M, Hungr O (2005) Debris-flow Hazards and Related Phenomena

Jordan G, Meijninger BML, Hinsbergen DJJ va., et al. (2005) Extraction of morphotectonic features from DEMs: Development and applications for study areas in Hungary and NW Greece. Int J Appl Earth Obs Geoinf 7:163-182.

https://doi.org/10.1016/j.jag.2005.03.003

Kavoura K, Sabatakakis N (2020) Investigating landslide susceptibility procedures in Greece. Landslides 17:127-145. https://doi.org/10.1007/s10346-019-01271-y

Kim MK, Yoo Y Il, Song JJ (2008) Methodology to quantify rock behavior around shallow tunnels by rock engineering systems. Geosystem Eng 11:37-42. https://doi.org/10.1080/12269328.2008.10541283

Kouli M, Loupasakis C, Soupios P, Vallianatos F (2010) Landslide hazard zonation in high risk areas of Rethymno Prefecture, Crete Island, Greece. Nat Hazards 52:599-621. https://doi.org/10.1007/s11069-009-9403-2

Liu BY, Nearing MA, Risse LM (1994) Slope gradient effects on soil loss for steep slopes. Trans Am Soc Agric Eng 37:18351840 . https://doi.org/10.13031/2013.28273

Malusà M, Mosca P (2002) Assetto strutturale duttile dei livelli superiori del Massicio d'Ambin (Alpi Occidentali). In: Guida all'escursione pre-Riunione: Il sistema Alpino-Appenninico nel Cenozoico (6-9 settembre 2002). Riunione della $81^{\circ}$ Riunione della Societa Geologica Italiana, Torino, Italia (1012 settembre). pp 83-86. (in Italian language)

Malusà M, Mosca P, Borghi A, et al. (2002) Approccio multidisciplinare per la ricostruzione dell'assetto tettonostratigrafico e dell'evoluzione metamorfico-strutturale di un settore di catena orogenica; l'esempio dell'Alta Valle di Susa (Alpi occidentali). In: Tra Alpi, Dinaridi e Adriatico; Atti dell'8o (super a) riunione estiva della Societa Geologica Italiana. (in Italian language)

Malusà M (2004) Post-metamorphic evolution of the Western Alps: kinematic constraints from a multidisciplinary approach (geological mapping, mesostructural analysis, fission-track dating, fluid inclusion analysis). PhD thesis, CNR-IGG - 
University of Torino, Torino, Italy.

Mazzoccola DF, Hudson JA (1996) A comprehensive method of rock mass characterization for indicating natural slope instabiblity. Q J Eng Geol 29:37-56.

https://doi.org/10.1144/GSL.QJEGH.1996.029.P1.03

Mosca P, Borghi A, Gattiglio M (2008) Storia pre-alpina ed alpina nel Massiccio di Ambin (Alpi Occidentali). In: Rendiconti Online Societa Geologica Italiana. pp 129-131. (in Italian language)

Oulx Municipality (2012) Variante di revisione generale al P.R.G.C. Verifiche di compatibilità idraulica ed idrogeologica. Progetto definitivo. (in Italian language)

Piana F, Fioraso G, Iracea A et al. (2017) Geology of Piemonte region (NW Italy, Alps-Apennines interference zone). J Maps 13(2): 395-405.

Polino R, Dela Pierre F, Borghi A, et al. (2002) Note illustrative della Carta Geologica d'Italia alla scala 1:50.000, Foglio 132152-153 Bardonecchia della Carta Geologica d'Italia - Regione Piemonte, Direzione Regionale dei servizi Tecnici di Prevenzione. Litografia Geda, Nichelino (TO) -Italia. (in Italian language)

Rickenmann D, Zimmermann M (1993) The 1987 debris flows in Switzerland: documentation and analysis. Geomorphology 8:175-189.

https://doi.org/10.1016/0169-555X(93)90036-2

Rozos D, Pyrgiotis L, Skias S, Tsagaratos P (2008) An implementation of rock engineering system for ranking the instability potential of natural slopes in Greek territory. An application in Karditsa County. Landslides 5:261-270.

https://doi.org/10.1007/s10346-008-0117-4

Servizio Geologico D'Italia, 2002. Carta geologica d'Italia alla scala 1:50.0000, Foglio 132-152-153 Bardonecchia. Regione Piemonte, Direzione Regionale dei servizi Tecnici di Prevenzione. Litografia Geda, Nichelino. Torino. (In Italian)

Skempton AW, Hutchinson J (1969) Stability of natural slopes and embankment foundations. In: State of the art report, Seventh International Conference on Soil Mechanics and Foundation Engineering. pp 291-340

Takahashi T (2007) Debris flow: mechanics, prediction and countermeasures. CRC Press. pp 1-572 https://doi.org/10.1007/BFo2830184

Tavoularis N, Koumantakis I, Rozos D, Koukis G (2018) The Contribution of Landslide Susceptibility Factors Through the Use of Rock Engineering System (RES) to the Prognosis of Slope Failures: An Application in Panagopoula and Malakasa Landslide Areas in Greece. Geotech Geol Eng 36:1491-1508. https://doi.org/10.1007/s10706-017-0403-9

Tiranti D, Bonetto S, Mandrone G (2008) Quantitative basin characterisation to refine debris-flow triggering criteria and processes: An example from the Italian Western Alps. Landslides 5:45-57. https://doi.org/10.1007/s10346-007-0101-4

Tiranti D, Cremonini R, Asprea I, Marco F (2016) Driving factors for torrential mass-movements occurrence in the Western Alps. Front Earth Sci 4. https://doi.org/10.3389/feart.2016.00016

Tiranti D, Cremonini R, Marco F, et al. (2014) The DEFENSE (debris Flows triggEred by storms - nowcasting system): An early warning system for torrential processes by radar storm tracking using a Geographic Information System (GIS). Comput Geosci 70:96-109.

https://doi.org/10.1016/j.cageo.2014.05.004
Tiranti D, Deangeli C (2015) Modeling of debris flow depositional patterns according to the catchment and sediment source area characteristics. Front Earth Sci 3.

https://doi.org/10.3389/feart.2015.00008

Tripathi NK, Gokhale KVGK, Siddiqui MU (200o) Directional morphological image transforms for lineament extraction from remotely sensed images. Int J Remote Sens 21:32813292.

https://doi.org/10.108o/014311600750019895

Tveite H (2015) The QGIS Line Direction Histogram Plugin. http://plugins.qgis.org/plugins/LineDirectionHistogram/

Umili G, Bonetto SMR, Mosca P, et al. (2020) In situ block size distribution aimed at the choice of the design block for rockfall barriers design: A case study along gardesana road. Geosci 10:1-21

https://doi.org/10.3390/geosciences10060223

Umili G, Bonetto S, Ferrero AM (2018) An integrated multiscale approach for characterization of rock masses subjected to tunnel excavation. J Rock Mech Geotech Eng 10:513-522. https://doi.org/10.1016/j.jrmge.2018.01.007

Vagnon F, Ferrero AM, Pirulli M, Segalini A (2015) Theoretical and experimental study for the optimization of flexible barriers to restrain Debris Flows. Geoingegneria Ambientale e Mineraria 145(2): 29-35.

Vagnon F, Ferrero AM, Umili G, Segalini A (2017) A Factor Strength Approach for the Design of Rock Fall and Debris Flow Barriers. Geotech Geol Eng 35:2663-2675. https://doi.org/10.1007/s10706-017-0269-x

Vagnon F (2020) Design of active debris flow mitigation measures: a comprehensive analysis of existing impact models. Landslides 17:313-333. https://doi.org/10.1007/s10346-019-01278-5

Vagnon F, Bonetto S, Ferrero AM, et al. (2020) Eurocode 7 and rock engineering design: The case of rockfall protection barriers. Geosci 10:1-16. https://doi.org/10.3390/geosciences10080305

Vagnon F, Ferrero AM, Alejano LR (2020) Reliability-based design for debris flow barriers. Landslides 17:49-59. https://doi.org/10.1007/s10346-019-01268-7

Vagnon F, Pirulli M, Yague A, Pastor M (2019) Comparison of two depth-averaged numerical models for debris flow runout estimation. Can Geotech J 56:89-101. https://doi.org/10.1139/cgj-2017-0455

van Westen CJ, van Asch TWJ, Soeters R (2006) Landslide hazard and risk zonation - Why is it still so difficult? Bull Eng Geol Environ 65:167-184. https://doi.org/10.1007/s10064-005-0023-0

VanDine DF (2009) Debris flow control structures for forest engineering: British Columbia Ministry of Forests Research Program, Victoria. Br Columbia 75 pp 8:1996

Vaz DA, Di Achille G, Barata MT, Alves EI (2012) Tectonic lineament mapping of the Thaumasia Plateau, Mars: Comparing results from photointerpretation and a semiautomatic approach. Comput Geosci 48:162-172. https://doi.org/10.1016/j.cageo.2012.05.008

Xu C, Xu X, Dai F, et al. (2013) Application of an incomplete landslide inventory, logistic regression model and its validation for landslide susceptibility mapping related to the May 12, 2008 Wenchuan earthquake of China. Nat Hazards 68:883-900.

https://doi.org/10.1007/s11069-013-0661-7 